\title{
Antibacterial Activity of Gamat Sea Cucumber Extract (Stichopus Variegatus) from Mentawai Islands against Streptococcus Viridans
}

\author{
Geistia Fad'ha \\ Undergraduate Student \\ Dentistry Faculty, Baiturrahmah University \\ Padang, West Sumatera, Indonesia \\ geistiafadha@gmail.com
}

\author{
Utmi Arma \\ Department of Oral Medicine \\ Dentistry Faculty, Baiturrahmah University \\ Padang, West Sumatera, Indonesia
}

\author{
Busman \\ Department of Oral Biology \\ Dentistry Faculty, Baiturrahmah University \\ Padang, West Sumatera, Indonesia
}

\begin{abstract}
Mentawai islands of West Sumatra province have a fairly extensive coastal areas and stored wealth of the sea has high economic potential, one of which is Teripang (Sea cucumbers). Besides having a high nutritional value sea cucumbers also have antibacterial activity against bacterial pathogens. In the field of dentistry, Streptococcus viridans is one of the main bacteria that cause dental health problems in oral cavity. This bacterium is normal flora in oral cavity that can cause dental caries. This study aims to determine antibacterial activity of extract of Sea Cucumber (Stichopus variegatus) of Mentawai Islands against Streptococcus viridans. Results of the study tested using ANOVA with a significance level of $5 \%$. The study revealed an average diameter of inhibitory zone gamat extract of sea Cucumber (Stichopus Variegatus) of Mentawai Islands against Streptococcus viridans. The highest concentration was $2.5 \%$ to the value of $8.45 \mathrm{~mm}$ in the medium category. P-value of the ANOVA test was $<0.05$ ( $p=0.012)$. Based on the results of the study concluded that there are antibacterial activity of extracts of Sea Cucumber Stichopus Variegatus of the Mentawai Islands against the bacteria Streptococcus viridans.
\end{abstract}

Keywords-antibacterial activity, stichopus variegatus, Streptococcus viridans

\section{INTRODUCTION}

Indonesia is an archipelagic country has a land area of 1.9 million $\mathrm{km}^{2}$ separate by strait and sea. According to its location, Indonesia is one the most strategic area in the world in the Western Indo-Pacific triangle with climate tropical. The waters of Indonesia are has a large coastal area one of which is the District of the Islands Mentawai West Sumatera Province. The coastal waters are stored wealth that has fishery potential which is quite large and has potential high economy, one of which is sea cucumbers $[1,2]$.

Sea cucumbers have so many nutrients that have high economy value. This type of biota is also known as suala, sea cucumber, beche de-mer or in the international market is known with teat fish. The number of species present throughout world around 1135 species. Indonesia has $10 \%$ of the species or 257 species but only 60 species identified. Only five of the species was most sought after species because it has economic value and nutritional value which is quite high. In the Mentawai Islands Sikabaluan sub-district species of Sea Cucumber that many have discovered is Stichopus variegatus, Holothuria scabra, Holothuria marmorata and Thelenota ananas. In Indonesia Sea cucumber was used as foodstuffs, especially by the community around the coast $[1,3,4]$.

Sea cucumbers have potential for as an antibacterial agent against pathogenic bacteria. Utilization as a source of antibacterial ingredients can gives a high value. Research by Ridwan found that sea cucumber has antibacterial effect to Streptococcus faecalis, Streptococcus viridans, Streptococcus pneumonia, and Staphylococcus aureus. The results of the experiments show inhibition of bacterial growth after being given Sea cucumber extracts from Holothuria atra, Holothuria scabra, and Bohadshi argus species $[1,3,5]$.

Research results or reports on antibacterial activities extract of Stichopus variegatus species from Island Mentawai against Streptococcus viridans until now have not existed. Therefore, the author interested to examine the antibacterial activity of the extract Stichopus variegatus of Mentawai Islands against Streptococcus viridians.

\section{MATERIALS AND METHODS}

This research was experimental laboratory research using the disc diffusion method (test Kirby \& Bauer). Stichopus variegatus was randomly taken from Mentawai Islands with tracing around a depth of 3-4 m and was identified at the Animal Ecology Laboratory Department of Biology FMIPA, Andalas University. Extraction and activity test antibacterial performed in 
January-March 2016 at the Biota Laboratory of Sumatra, Andalas University. Number of loops done in this study was using Federer's general formula $(\mathrm{t}-1)(\mathrm{r}$ $-1) \geq 15$. Big repetition taken 4 times

\section{A. Tools}

The tools used in this research include scissors, filter paper, dark bottles 2.5 liters, test tube, $250 \mathrm{ml}$ Erlenmeyer tube, Rotary Buci Evaporator R 210, distillation, Whatman filter paper, Rotary 2000 $\mathrm{ml}$ flask, spectrometer, funnel, digital scales, petri dish, spatula, micro pipette, needle ose, cotton bud, corn yarn, newsprint, spiritus lamp, calipers, autoclave, hot plate, tweezers, sterile gauze and cotton.

\section{B. Material}

The main ingredient used is Sea cucumbers (Stichopus variegatus), Streptococcus viridans, 96\% ethanol, $70 \%$ alcohol, nutrient agar, $\mathrm{NaCl} 0.9 \%$, Chlorhexidine and DMSO (dimethyl sulfoksid).

\section{Sterilization tool}

Tools to be used for testing washed and dried. Test tube and Erlenmeyer was closed with gauze filled with cotton. Then petri dish, test tube, erlenmeyer, paper and discs cotton bud wrapped in newspaper and sterilized in an autoclave with pressure 1 atm and temperature $121^{\circ}$ $\mathrm{C}$ for 15 minutes. Ose needles and tweezers sterilized by burning with fire. Laminar air flow cabinet was cleaned with $70 \%$ alcohol and then sterilized with UV lamp for 10 minutes [10].

\section{Maceration and preparation Stichopus variegates}

The result of the first cocktail of Stichopus variegatus was filtered using Whatman filter paper and inserted into the dark bottle. Cut the Stichopus variegates into a small with a size of approximately 2-4 $\mathrm{cm}$ use scissors to speed up the maceration process. After that, the maceration was done again with $96 \%$ ethanol for $3 \times 24$ hour.

The obtained gamat is filtered and put into the dark bottle. This treatment is done 4 times. After maceration results were obtained, distillation was carried out to reduce the amount $96 \%$ ethanol solvent from maceration results. Then the distillation was rotate using a rotary evaporator R-210 Buci to obtain concentrated maserate from sea cucumbers.

Concentration of Stichopus variegates extract used in this study was $20 \% ; 10 \% ; 5 \% ; 2.5 \% ; 1.25 \%$ and $0.625 \%$. Material which is used as an extreme solvent of Stichopus variegatus is a DMSO solution.

\section{E. Preparation nutrient agar}

Enter the 20 grams of powder nutrient agar (NA) into the Erlenmeyer flask then dissolve with $1000 \mathrm{~mL}$ aquadest, then heat above the hotplate and stir until dissolved. Wrap with newspaper then sterilized with autoclave at $121^{\circ} \mathrm{C}$ for 15 minutes.
TABLE I. CONCENTRATION OF STICHOPUS VARIEGATUS EXTRACTS

\begin{tabular}{|c|c|c|}
\hline $\begin{array}{c}\text { Stichopus Variegatus } \\
\text { Extracts (gr) }\end{array}$ & $\begin{array}{c}\text { Final Volume } \\
(\mathbf{m L})\end{array}$ & $\begin{array}{c}\text { Concentration } \\
(\mathbf{\%})\end{array}$ \\
\hline 4 & 20 & $20 \%$ \\
\hline 2 & 20 & $10 \%$ \\
\hline 1 & 20 & $5 \%$ \\
\hline 0,5 & 20 & $2,5 \%$ \\
\hline 0,25 & 20 & $1,25 \%$ \\
\hline 0,125 & 20 & $0,625 \%$ \\
\hline
\end{tabular}

\section{F. Preparation of bacterial suspension test}

Bacteria planted on nutrient agar tilted in test tube and incubated at $37^{\circ} \mathrm{C}$ for $1 \times 24$ hours, then the bacteria will be tested in suspense manner in liquid medium up to $0.9 \% \mathrm{NaCl}$ physiological solution obtained turbidity according to standard 0.5 McFarland or worth the amount bacterial 1x10 $8 \mathrm{CFU} / \mathrm{ml}$.

\section{G. Antibacterial activity test}

Antibacterial activity test was performed using the method diffusion. This method looks at the clear area on media to indicate the presence of growth resistance microorganisms by antimicrobial agents on the surface of the media order. The microbial suspension is thoroughly absorbed on nutrient agar media using a cotton bud. Back of the petri dish previously marked with paper according to extract concentration. Then take the disc paper and drip concentration using fluid micro pipette, then placed on the media. After that wrap the petri dish with plastic wrap and incubated at $37^{\circ} \mathrm{C}$ for 1 x 24 hours. After 24 hours observed the microbial growth test and measured drag zone diameter. The zone measured by looking at the clear zone then measured its diameter (Figure 1). The data obtained were analyzed statistically with ANOVA test with $5 \%$ of significance level by using the app SPSS for Windows 16.0.
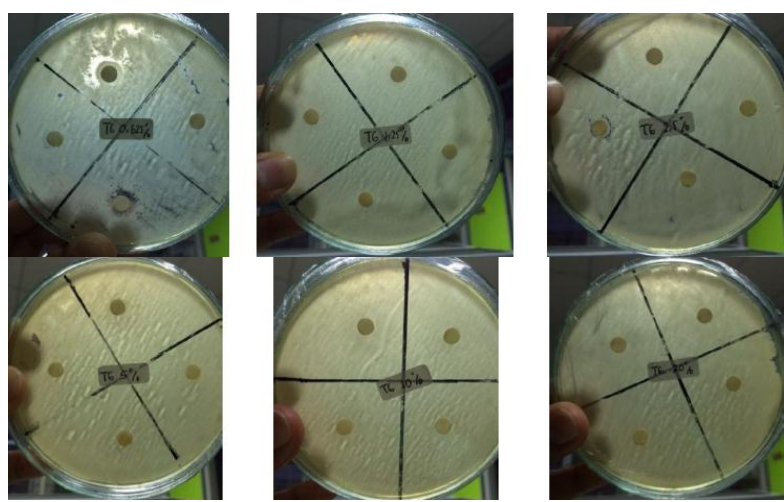

Figure 1. Bacteria planted on media growth of nutrient agar.

\section{RESULTS}

TABLE II. AVERAGE DIAMETER OF INHIBIT ZONE EXTRACT SEA CUCUMBER SEA CUCUMBERS

\begin{tabular}{|c|c|c|c|c|c|c|c|c|}
\hline \multirow{2}{*}{ Repeater } & \multicolumn{7}{|c|}{ Concentration } & \multirow{2}{*}{$\begin{array}{c}\text { Con- } \\
\text { trol + }\end{array}$} \\
\cline { 2 - 8 } & $\begin{array}{c}\mathbf{0 . 6 2 5} \\
\text { Con- } \\
\text { trol - }\end{array}$ & $\begin{array}{c}\mathbf{1 . 2 5} \\
\mathbf{\%}\end{array}$ & $\mathbf{2 . 5 \%}$ & $\mathbf{5 \%}$ & $\mathbf{1 0 \%}$ & $\begin{array}{c}\mathbf{2 0} \\
\mathbf{\%}\end{array}$ & & \\
\hline I & 9.2 & 8.7 & 9.4 & 6.2 & 7.7 & 6.2 & & \\
\hline II & 8.7 & 7.8 & 8.4 & 8.5 & 6.3 & 6.5 & & \multirow{2}{*}{0.0} \\
\hline III & 7.5 & 8.1 & 7.5 & 8.3 & 7.6 & 6.8 & 108 & \\
\hline IV & 7.3 & 7.6 & 8.5 & 7.5 & 7.5 & 6.1 & & \\
\hline Average & 8.17 & 8.05 & 8.45 & 7.63 & 7.27 & 6.4 & & \\
\hline
\end{tabular}




\section{DISCUSSION}

Antibacterial activity is affected by several factors include extract concentration, antibacterial compounds, power diffusion and types of bacterial extracts [11]. Based on the results on Table II, the average diameter of inhibit zone extract of Stichopus variegatus of Mentawai Islands against bacteria Streptococcus viridans is highest in concentration of $2.5 \%$ with a value of $8.45 \mathrm{~mm}$ medium category according to Davis and Stout (1971) [12]. The concentration of $2.5 \%$ is the maximum concentration that can inhibit Streptococcus viridans growth, whereas on 5\%, $10 \%$ and $20 \%$ concentrations showed decrease in drag zone diameter against Streptococcus viridans. Decrease in drag zone diameter because bacteria can be sensitive or resistant to certain antibacterial. If bacteria are sensitive to a drug, then the bacteria will still grow despite drug administration. This suggests antibacterial used exceeds the threshold (over dose), will causing bacteria to be immune to antibacterial. In addition, the decrease in diameter zone resistor bias was due to extract unable to diffuse. The extract concentration which is too dense makes the extract not capable of maximal diffusion. Concentration that is too high causing active substances in the extract cannot dissolve perfectly because the saturation of the extract $[13,14,15]$.

The results showed Stichopus variegatus extract of Mentawai Islands with concentrations of $20 \%, 10 \%$, $5 \%, 2.5 \%, 1.25 \%$ and $0.625 \%$ is in the medium category. Control (+) in this study using Chlorhexidine, the average diameter of the zone Chlorhexidine drag on Streptococcus viridans growth was in the strong category of $10.8 \mathrm{~mm}$.

According to Maleki et al. (2008) extract concentration that is too concentrated causing the extract difficult to diffuse maximally into medium containing inoculums [14]. Concentration of extract that is higher could make saturation that causing active compounds contained in the extract not dissolved perfectly. Stichopus variegatus extract activity of the Mentawai Islands on Streptococcus viridans growth already in the medium category with the lowest concentration $(0.625 \%) 9.2 \mathrm{~mm}$.

One of the secondary metabolite compounds contained on Teripang is triterpene saponins glcosides. Saponins have antibacterial activity [16]. Saponins are a class of secondary metabolites compounds that can inhibit or killing microbes in a way interact with the sterol membrane. Saponins is classified as bacteriostatic to bacteria because of the ability in inhibit bacterial growth. Saponins interferes the permeability of bacterial cell membrane, which lies directly below the cell wall. It becomes difficult for saponins to damage the permeability of cell membranes because the cell wall is also not easily tampered [17].

The researchers suggested that isolation be done antibacterial in the extract of Sea Cucumber Stichopus variegatus so that it can be used as a mouthwash for preventing the occurrence of dental caries.

Based on the results it can be concluded that antibacterial activity of Stichopus variegatus extract from Mentawai Island against Streptococcus viridans at medium category. Concentration of $2.5 \%$ is the maximum concentration can inhibit Streptococcus viridans growth. It also can be concluded that Stichopus variegates extract from Manawa Island has antibacterial activity against Streptococcus viridian.

\section{REFERENCES}

[1] J. Marty, A. Ungroom, T. Wincanton, "Budi day tripping, Jakarta: Penumbra Swadaya, 1994.

[2] Iswanto, Potensi laut dan samudra kita, Bandung: PT Intan Sejati, 2007.

[3] M.G.H. Kordi, A to $\mathrm{Z}$ budi daya biota akuatik untuk pangan, kosmetik, dan obat-obatan, Ed. 1, Yogyakarta: Lily Publisher, 2010.

[4] D. Elfidasari, N. Noriko, N. Wulandari, A.T. Perdana, "Identifikasi jenis teripang genus holothuria asal perairan sekitar kepulauan seribu berdasarkan perbedaan morfologi," Jurnal AlAzhar Indonesia Seri Sains dan Teknologi, vol. 1(3), 2012.

[5] A. Rasyid, "Identifikasi senyawa metabolit sekunder serta uji aktivitas antibakteri dan antioksidan ekstrak metanol teripang Stichopus Hermanii," Jurnal Ilmu dan Teknologi Kelautan Tropis, vol. 4(2), 2012.

[6] S. Nimah, W.F. Ma'ruf, A. Trianto, 'Uji bioaktivitas ekstrak teripang pasir (Holothuria scabra) terhadap bakteri Pseudomonas aeruginosa dan Bacillus cereus," Jurnal Perikanan, vol. 1(2), 2012.

[7] L. Samaranayake, Essential microbiology for dentistry, $3^{\text {rd }}$ ed., USA: Churchill Livingstone Elsevier, L. 2006.

[8] U. Kawuryan. (2015, January 10) Hubungan pengetahuan tentang kesehatan gigi dan mulut dengan kejadian karies gigi anak SDM Kleco II kelas V dan VI Kecamatan Laweyansurakarta. Available: http://etd.eprints.ums.ac.id/897/1/J210040006.pdf.

[9] Kementrian Kesehatan RI, Situs kesehatan gigi dan mulut. Jakarta: Pusat Data dan Informasi Kementrian Kesehatan RI, 2014.

[10] Busman, F. Betty, "Uji aktivitas antibakteri dan fitokimia tanaman obat luka (Cestrum elegans) (Solanaceae)," Jurnal Penelitian dan Kajian Ilmiah, vol. V(25), 2011.

[11] I.P. Sari, M.A. Wibowo, S. Arreneuz, "Aktivitas antibakteri ekstrak teripang butoh keling (Holothuria leucospilota) dari Pulau Lemukutan terhadap bekteri Propioni bacterium acnes dan Staphylococcus epidermis," Jurnal Program Studi Kimia, Fakultas MIPA, Universitas Tanjungpura, 2015.

[12] Davis, Stout, "Disc plate method of microbiological antibiotic essay," Journal of Microbiology, vol. 22(4), 1971.

[13] J. Kee, R.H. Evelyn, Farmakologi: Pendekatan proses keperawatan. Jakarta: EGC, 1996.

[14] S. Maleki, S.M. Seyyednejad, M.N. Damabi, H. Motamedi, "Antibacterial activity of the fruits of Iranian torilis leptophylla againts some clinical pathogens," Pakistan Journal of Biological Sciences, vol. 11(9), 2008.

[15] D. Saraswati, "Pengaruh konsentrasi ekstrak daun sirih terhadap daya hambat Escherichia Coli," Jurnal Health \& Sport, vol. 3(2), 2011.

[16] Nikham, E.B. Taty, "Uji bahan baku antibakteri dari buah mahkota dewa (Phaloria Macrocarva (Scheff) Boerl). Hasil iradiasi gamma dan antibiotik terhadap bakteri pathogen," Prosiding Pertemuan Ilmiah Ilmu Pengetahuan dan Teknologi Bahan, 2012.

[17] Zahro, Latifatuz, R. Agustini, "Uji efektivitas antibakteri ekstrak kasar saponin jamur tiram putih (Pleurotus Ostreatus) terhadap Staphylococcus Aureus dan Escherichia Coli," UNESA Journal of Chemistry, vol. 2(3), 2013. 